\title{
Instituições e Competitividade no Arranjo Calçadista do Vale do Sinos
}

\section{Institutions and Competitiveness in the Vale do Sinos' Footwear Industrial Cluster}

Achyles Barcelos da Costa ${ }^{1}$

Resumo: Setores intensivos em mão-de-obra no Brasil como os de calçados, de móveis e de confecções passam por fortes pressões concorrenciais, em decorrência da presença em seus mercados de atuação de competidores asiáticos com ambiente produtivo mais favorável à competitividade. Concorrer em preços torna-se cada vez mais problemático a esses setores e há a necessidade de transitar para outros atributos de competitividade. Em atividades produtivas povoadas por micro e pequenas empresas, a presença de instituições que forneçam serviços reais adequados a novos atributos competitivos é fundamental para a sobrevivência desses portes de empresas. Pesquisa realizada em 2006 com instituições e pequenas empresas do arranjo de calçados do Vale do Sinos mostra que a articulação entre esses agentes nessa direção ainda é relativamente limitada. O grau de associativismo empresarial é baixo, particularmente entre pequenas empresas. Já as empresas de grande porte apresentam maior grau de autonomia para estabelecer estratégias próprias de ajuste à nova situação.

Palavras-chave: Instituições. Competitividade. Arranjo calçadista. Vale do Sinos.

Abstract: Brazilian economic activities that are labor intensive as the one of footwear, furniture, and clothes, go by strong competitive pressures, due to the presence in their markets of Asian competitors with more favorable productive atmosphere to the competitiveness. To compete in prices becomes more and more problematic and there is the need to transit for other attributes of competitiveness. In economic activities populated by small and medium enterprises, the presence of institutions that supply appropriate real services to new competitive attributes is fundamental for the survival of those companies. Research accomplished in 2006 with institutions and small firms of the footwear industy of Vale do Sinos, in the south of Brazil, display that the articulation among those agents in that direction is still relatively limited. The degree of business association is low, particularly among small companies. In turn, the big enterprises present larger autonomy degree to establish own strategies of adjustment to the new situation.

$1 \quad$ Economista. Professor titular aposentado - UFRGS. Professor da Unisinos. E-mail: achylesbc@ unisinos.br 
Keywords: Institutions; Competitiveness. Footwear cluster. Vale do Sinos.

JEL Classification: L11; L67.

\section{Introdução ${ }^{2}$}

A dinâmica do ambiente competitivo internacional tem colocado renovados desafios à sobrevivência de empresas e setores produtivos, particularmente àqueles pertencentes a países de menor desenvolvimento relativo como o Brasil. Atividades desenvolvidas no País como a de calçados, de móveis, de confecções, além de outras, têm estado sujeitas a fortes pressões competitivas, devido à presença em seus mercados de atuação de produtos oriundos de países cujas condições produtivas se mostram mais favoráveis à competitividade.

A resposta bem-sucedida de empresas e setores aos desafios que essa realidade apresenta depende de capacitações produtivas, tecnológicas e organizacionais, bem como de arranjos institucionais, que consigam desenvolver para se adaptar às novas normas de concorrência. Movimentos industriais nessa direção em determinados setores têm-se beneficiado de experiências internacionais de atividades que se mostraram exitosas em promover o crescimento com base em aglomerações empresariais geograficamente localizadas. Na década de 1970 e em períodos seguintes, em um quadro de fraco dinamismo econômico ocorrido nos principais países industrializados, notou-se que determinadas regiões geográficas ostentavam alto desempenho, e se creditava a maior performance observada à forma como se organizavam as atividades produtivas nesses locais. As regiões italianas da Emilia Romagna, da Toscana, e outras, núcleo do que ficou conhecido como Terceira Itália, tornaram-se casos emblemáticos por exibirem elevado crescimento econômico, tendo como base um modo particular de organizar a produção.

A denominação de cluster ou distrito industrial que se atribuiu a essa maneira de organizar a atividade econômica ${ }^{3}$ remonta a Alfred Marshall

2 Este trabalho, com algumas modificações, foi apresentado no Encontro Nacional de Economia, 35: 2007, Recife, PE. Anais: ANPEC, 2007. (Disponível em CD-ROM). O autor agradece às sugestões de um parecerista anônimo da Revista.

3 Há ainda outras denominações para esse modelo. Em seu celebrado livro The Second Industrial Divide, Piore e Sabel (1984) defendem a ideia de que a busca de flexibilidade do sistema como resposta às dificuldades do modelo de produção em massa - em decorrência de rigidez produtiva apresentada por esse último - manifestaram-se de duas formas. Uma foi a exibida por organização industrial japonesa, através de suas empresas em rede. A outra foi o modelo italiano com suas redes de empresas, que os autores chamaram de "especialização flexível". Embora palavras diferentes procurem expressar conteúdos distintos, outras expressões, como cluster, arranjos produtivos locais, sistemas locais de produção, podem também ser encontradas com significado semelhante ao de distrito industrial. O ponto a ser ressaltado é que o aglomerado de empresas em proximidade geográfica e a presença de outras instituições, além do 
que, em sua obra Principles of Economics de 1890, dedicou um capítulo para discutir os ganhos em eficiência que pequenas empresas poderiam obter quando aglomeradas em proximidade espacial. Contudo, à época em que Marshall elaborou sua análise assistiu-se também, particularmente nos Estados Unidos, ao desenvolvimento e à consolidação da grande empresa industrial como forma organizacional da produção, obtendo eficiência a partir da escala de suas operações e pela integração vertical (CHANDLER, 1959). A pequena empresa, desde então, passou a ser vista como uma organização inadequada para a busca de produtividade devido às suas limitações gerenciais, tecnológicas, financeiras, exibindo empregos de baixa qualificação, e sendo incapaz de dar sustentação ao crescimento da economia. A sua sobrevivência no sistema era considerada marginal, subordinada à grande empresa ou atuando em nichos de mercado considerados pouco atrativos às unidades produtivas maiores ou, ainda, servindo como amortecedor para o emprego durante as fases de descenso dos ciclos econômicos.

O que chamou a atenção no desempenho daquelas regiões italianas foi que as atividades econômicas ali desenvolvidas eram feitas por uma miríade de empresas de pequeno porte, que se apresentavam aglomeradas no espaço geográfico. ${ }^{4}$ Isso contrastava com aquela visão de que empreendimentos de pequena escala teriam poucas chances de serem dinâmicos. A questão então da viabilidade da pequena empresa não estava no seu porte em si, mas em seu isolamento na atividade produtiva (SEGENBERGER; PYKE, 1991). Ao se aproximar espacialmente de empresas dedicadas à mesma atividade e a outras correlatas, ela poderia se beneficiar de externalidades propiciadas pela divisão do trabalho. Em outras palavras, o cluster de empresas em um determinado espaço dá ensejo a que se obtenham ganhos de produtividade em decorrência de especialização produtiva e de acesso a recursos e informações que seriam dificeis ou muito custosos de serem alcançados sob condições isoladas. A partir dessa observação difundiu-se a ideia de que pequenas empresas aglomeradas, junto com características locais associadas ao território, à cultura e a laços sociais, também seriam capazes de fornecer bases para o crescimento econômico. ${ }^{5} \mathrm{~A}$ ideia é que

mercado, influem no desempenho econômico.

4 O cluster de empresas não precisa necessariamente ser constituído apenas por empresas de pequeno porte, embora seja essa a experiência italiana.

5 No âmbito das estratégias de desenvolvimento de países e regiões, ganhou força a convicção de que o sucesso econômico não estava apenas em reproduzir internamente os padrões de desenvolvimento de países que detinham a liderança tecnológica e que ditavam os rumos a seguir. De uma maneira geral, países em atraso relativo - a exemplo daqueles da América Latina - procuravam copiar as práticas externas através do caminho da substituição de importações. O que a experiência italiana e de outras regiões indicavam é que seria possível também o desenvolvimento endógeno. Ou seja, a eficiência não estaria associada apenas 
a competitividade de determinado setor econômico não estaria associada apenas ao baixo custo de produção, devido à posse de algum fator ou recurso em condições vantajosas ou à escala, mas à maior eficiência assentada na especialização das empresas do aglomerado e na possibilidade de concorrência em flexibilidade no atendimento a uma maior fragmentação da demanda (SENGENBERGER; PYKE, 1999; VARALDO; LUCA, 1996). Cogitou-se, inclusive, que o aglomerado de empresas poderia fazer sua inserção internacional em mercados globalizados e fragmentados de modo tão ou mais eficiente que a da grande empresa (GURISATTI, 1999).

Embora não se tenha chegado a um consenso na discussão teórica acerca do destino do fordismo e do papel da grande empresa, bem como da forma futura que assumiria a organização industrial capitalista (COSTA, 1998), parece inegável que o conceito de distrito industrial veio trazer novos olhares sobre a presença da pequena empresa na atividade econômica. ${ }^{6}$ A difusão do conceito na academia e entre policy makers deve-se a que se tornou um instrumento útil para interpretar a dinâmica da pequena empresa e na formulação de políticas públicas para esse porte de estabelecimento produtivo. O ponto a ressaltar é que conquanto o aglomerado de pequenas empresas não seja um substituto para o estabelecimento de grande porte, ele mostrou, por outro lado, que a pequena empresa não é, em si, inviável.

Note-se, contudo, que a experiência então observada de aglomerados de pequenas empresas que se tornou benchmark para outros estudos refere-se àquela praticada em países industrializados. Por serem aqueles clusters industriais resultado de desenvolvimento no tempo, as suas características e dinâmica não necessariamente são passíveis de serem encontradas quando exercidas em outros locais, cuja evolução econômica, trajetória cultural e política, bem como as relações sociais praticadas, são produtos também de sua história. Ou seja, as performances econômicas, os atributos de competitividade, e as próprias características da organização industrial encontradas em países de menor desenvolvimento relativo obedecem igualmente às suas idiossincrasias.

Neste trabalho busca-se aprofundar a reflexão acerca da direção que deverão seguir os ajustes empreendidos por empresas brasileiras de calçados e instituições vinculadas ao setor, particularmente no arranjo produtivo do Vale do Sinos, no Rio Grande do Sul. O argumento central é de que frente aos novos desafios competitivos é preciso considerar não

ao tamanho da empresa, independentemente do território de sua atividade econômica - como no caso da empresa multinacional - mas na exploração adequada de recursos e características das localidades.

6 De acordo com Sengenberger e Pyke (1999), não se trata de afirmar, contudo, que a pequena empresa é mais eficiente que a empresa de grande porte ou vice-versa. 
só aspectos de sua organização industrial, mas também a história de sua inserção no mercado internacional e os fatores que têm determinado a dinâmica competitiva dessa atividade.

A produção de calçados tem mostrado ser uma atividade adequada para ser desenvolvida em clusters de empresas geograficamente situadas, sendo então observada sob essa forma em diferentes regiões do mundo. ${ }^{7}$ Isso também ocorre no Brasil, sendo a localização territorial de seus principais aglomerados, como o do Vale do Sinos e de Franca, o resultado de processo de formação da economia brasileira. A sua inserção no mercado externo beneficiou-se dessa existência agrupada, com suas externalidades e ação institucional, credenciando-se no atendimento à demanda externa de calçados. Mas esses não foram os únicos e principais determinantes do seu sucesso. Contribuiu também o fato de ter início à época um movimento de produtores de países industrializados no deslocamento da manufatura dessa atividade -particularmente o segmento de produção em escala e de baixo preço - para regiões do mundo que exibiam melhores condições produtivas. Esse ambiente mais favorável referia-se basicamente a custos baixos de produção. Sob esse aspecto, oferta abundante e barata de mão-de-obra, bem como câmbio competitivo, constituíam-se em fatores cruciais para o sucesso econômico.

O deslocamento de produtores de calçados por outros competidores que apresentam custos de produção inferiores é recorrente nesse mercado. É por isso que se considera nesse meio industrial que a atividade de produzir calçado assume certa característica "nômade", deslocando-se no espaço geográfico em busca de mão-de-obra barata e com oferta elástica. Note-se, ainda, que a inserção no exterior da produção brasileira de calçados ocorre de forma subordinada: ela é subcontratada, produzindo para marcas internacionais, intermediada por agentes de exportação, e atuando no segmento de mercado de calçados de preço baixo. A trajetória de expansão de empresas, o próprio desenvolvimento institucional e suas ações estiveram, assim, condicionados pelo atributo competitivo do setor.

A partir dos anos 1990, a indústria passa a se defrontar com pressões competitivas oriundas do surgimento de novos concorrentes que se beneficiam de custos mais baixos de produção, devido à vantagem comparativa do preço de sua mão-de-obra. Diante desse quadro, torna-se cada vez mais problemática a sua sustentação no exterior com base apenas nesse atributo. Há, portanto, necessidade de se trilhar novos caminhos. Competir com base em marca própria e vendas diretas a importadores e a consumidores finais em distintos mercados geográficos, bem como atender pequenos volumes de pedidos, vêm se mostrando ser um caminho factível. Para isso deve-

7 Por exemplo, em Brenta e Marche, na Itália; em Pusan, na Coréia do Sul; em Guadalajara e Leon, no México; e em Elche, na Espanha. 
se adequar a estrutura produtiva para atender a essa estratégia. Grandes empresas têm se estruturado em alguns desses elementos. Igualmente, instituições de apoio vinculadas ao setor têm procurado desenvolver serviços no auxílio a empresas, particularmente às de menor porte, que são as que apresentam maiores limitações.

O que se buscou empiricamente neste trabalho foi identificar, de maneira ainda exploratória, como empresas e instituições do setor procuram se ajustar para fazer frente a esse ambiente competitivo. Para tanto, o artigo está organizado da seguinte maneira. Além dessa Introdução são apresentadas mais quatro seções. Na segunda seção expõe-se o conceito de distrito industrial como modelo de organização industrial. O objetivo é mostrar as propriedades que, de um modo geral, a literatura indica como auxiliando a performance competitiva das unidades produtivas. Comentários críticos são feitos en passant, apenas para chamar a atenção para pontos controversos, pois a intenção principal é ressaltar os elementos que os distinguem como forma particular de organizar atividades econômicas. A terceira seção, de natureza sintética, é dedicada precipuamente a distinguir o papel da ação institucional e de serviços reais na promoção do aglomerado de empresas. A quarta seção, por sua vez, destaca fatores relacionados à história do setor, ao retratar a sua trajetória competitiva e formação institucional, bem como apresenta informações empíricas em relação ao ajuste de empresas e instituições diante de novas pressões competitivas. A quinta seção encerra o texto com as Considerações Finais, em que se faz um balanço do material discutido.

\section{Distrito Industrial como Modelo de Organização da Atividade Produtiva}

Uma contribuição importante da literatura dos distritos aos estudos de organização industrial foi questionar a visão de que apenas a grande escala e a atuação de forças de mercado - cujos agentes agem de forma individual e autointeressada, tendo como norte unicamente o cálculo econômico - seriam os responsáveis por desempenhos econômicos superiores. O enfoque dos distritos industriais enfatiza que pequenas empresas atuando em cooperação através de uma miúda divisão do trabalho em aglomeração espacial, juntamente com instituições e relações sociais que se desenvolvem ao longo do tempo e que formam o ambiente social sob o qual a atividade econômica se realiza, são também capazes de produzir crescimento econômico. ${ }^{8}$

$8 \quad$ O "também" aqui empregado significa que a pequena empresa pode igualmente ser funcional ao sistema. 
O conceito de cooperação para o entendimento da performance produtiva, contudo, é antigo na teoria econômica. Adam Smith procurou mostrar que a riqueza das nações seria devida aos aumentos de produtividade alcançados através da divisão do trabalho. A ilustração feita por Smith na produção de alfinetes indica que os trabalhadores, ao se especializarem na execução de fases ou de tarefas da fabricação do produto, em vez de cada trabalhador buscar fabricá-lo na sua totalidade, têm sua produtividade multiplicada (SMITH, [1776]1979). Em O Capital, Marx ([1867]1983, p. 259-262) dedica o capítulo XI - Cooperação - à análise dos benefícios da atuação conjunta dos trabalhadores, que se constituem em uma força global de produção:

A forma de trabalho em que muitos trabalham planejadamente lado a lado
e conjuntamente, no mesmo processo de produção ou em processos de
produção diferentes, mas conexos, chama-se cooperação [...] Em compa-
ração com uma soma igual de jornadas de trabalho isoladas individuais a
jornada de trabalho combinada produz maiores quantidades de valor de
uso, diminuindo por isso o tempo de trabalho necessário para produzir
determinado efeito útil [...] Ao cooperar com outros de um modo planeja-
do, o trabalhador se desfaz de suas limitações individuais e desenvolve a
capacidade de sua espécie.

A cooperação referida por Smith e Marx é aquela que ocorre no interior da fábrica. Para que produza efeitos em termos de aumentos de produtividade, é necessário que o fracionamento do processo de trabalho, cujas fases e tarefas são executadas de forma cooperativa, seja coordenado por alguém ou por algum mecanismo. Sob o capitalismo, o controle do processo de trabalho é atributo do capitalista ou de seus prepostos. De acordo com Marx ([1867]1983, p. 263):

Todo trabalho diretamente social ou coletivo executado em maior escala requer em maior ou menor medida uma direção, que estabelece a harmonia entre as atividades individuais e executa as funções gerais que decorrem do movimento do corpo produtivo total, em contraste com o movimento de seus órgãos autônomos. Um violinista isolado dirige a si mesmo, uma orquestra exige um maestro. Essa função de dirigir, superintender e mediar torna-se função do capital, tão logo o trabalho a ele subordinado torna-se cooperativo. Como função específica do capital, a função de dirigir assume características específicas.

Na fábrica, a coordenação das fases e tarefas fracionadas é realizada de maneira hierárquica em uma linguagem verbalizada ou codificada em instruções que são compreensíveis aos partícipes do processo (PIORE, 2001). Quando fases do processo de trabalho e componentes do produto 
se transformam em atividades isoladas, o capitalista individual já não consegue mais coordenar o processo produtivo como quando esse tinha lugar no interior da empresa. Passa, então, a ter que adquiri-los no mercado. ${ }^{9}$ Por isso, a coordenação do processo produtivo tem de ser realizada de outra forma: via sistema de preços, ou através de subcontratação. Em economias de mercado os preços constituem-se em um mecanismo de transmissão de informações, pois além de expressarem monetariamente os valores das mercadorias podem indicar ainda uma maior ou menor qualidade do objeto trocado e sinalizam também a escassez ou a abundância relativa de recursos e de produtos. A sua linguagem é facilmente compreensível pelos agentes, atuando no dizer de Piore (2001) como um tipo de Código Morse. ${ }^{10}$

Dá-se por suposto que na coordenação pelo mercado todas as informações e conhecimentos relevantes sobre o produto comercializado sejam adquiridos ao se efetivar a transação, embora o adquirente não necessariamente precise dominá-los. Quando uma empresa compra um componente ou serviço produtivo no mercado, ela está interessada na utilidade que ele lhe proporciona, ou seja, em seu valor de uso. O saber tecnológico necessário para sua feitura está plasmado no próprio produto. Há ainda nessa troca uma impessoalidade, particularmente se há vários fornecedores do mesmo componente ou serviço. Na coordenação hierárquica esses conhecimentos são desenvolvidos na própria empresa, internalizando essas atividades.

Quando o trabalho é dividido e as fases e os componentes são feitos separadamente, por exemplo, por pequenas empresas ou, ainda, quando o conhecimento sobre as inovações que essas empresas necessitam para se adaptar às mudanças que os mercados exigem não é passível de ser transmitido pelo sistema de preços, isto é, esse conhecimento é transmitido em uma linguagem especial ou real, então, de acordo com Piore (2001), é necessária a presença do que o autor chama de "intermediários sociais", cuja função é manter um fluxo de informações entre os agentes, indicar oportunidades, facilitar o acesso a bens públicos, entre outros. Isso permitiria que estabelecimentos de pequeno porte, por terem escalas de produção reduzidas, superem deficiências a elas associadas. Essas unidades, de

$9 \quad$ Alchian e Demsetz ([1972]1996) usam a seguinte imagem para descrever essa situação: "Quando um produtor de madeira emprega um marceneiro, a cooperação entre especialistas é feita no interior da empresa e quando um marceneiro compra madeira de um produtor, a cooperação se produz entre dois mercados (ou entre duas empresas)".

10 A subcontratação não apresenta a mesma plasticidade do mecanismo de preços, pois alguma particularidade associada ao produto ou ao serviço, para ser feita, necessita ainda de uma interação mais estreita entre contratado e contratante. É semelhante ao que ocorreria no interior da empresa contratante, quando ela mesma fabricava o componente ou executava a fase ou a tarefa produtiva. 
um modo geral, não têm autonomia para, em âmbito individual, absorver, adaptar ou desenvolver inovações capazes de lhe garantir sobrevivência e competitividade nos mercados. No distrito industrial a emergência desses agentes seria facilitada pela existência de laços sociais e de confiança que dão "cola" entre a comunidade e o cluster de empresas. É preciso, então, que instituições externas às empresas, e vinculadas ao aglomerado, sejam criadas para superar essas restrições. De acordo com You (1994), o estabelecimento de um marco institucional com essa finalidade pode ser fruto tanto de movimentos cooperativos entre agentes locais, quanto de iniciativas de governos em seus distintos âmbitos.

A literatura sobre os distritos industriais representou um avanço na análise sobre a performance produtiva ao indicar que essa não estaria associada apenas às economias externas oriundas da cooperação pela divisão de tarefas, da criação de um mercado de trabalho local, do surgimento de ramos auxiliares e pelo enraizamento dos saberes em relação à fabricação do produto, enfim, pela industrial atmosphere, como teorizado por Marshall ([1890]1982). Para que o distrito seja dinâmico, acompanhe as mudanças do mercado, mantenha a competitividade e, principalmente, preserve as características locais que dão identidade ao produto, é necessária uma base mais ampla de atributos: laços sociais e instituições.

A integração social que ocorre no local, fruto da ação concertada entre instituições e comunidade, em sintonia com o aglomerado de empresas, constitui-se em uma das principais características de um distrito industrial. Becattini ([1990]1992, p. 38), um dos pioneiros no estudo do assunto, expressa da seguinte maneira a simbiose entre os aspectos econômicos e os sociais encontrados em distritos industriais:

Defino distrito industrial como sendo uma entidade socioterritorial, que se caracteriza pela presença ativa de uma comunidade de pessoas e de um conjunto de firmas que se ligam natural e historicamente em uma mesma área. No distrito, ao contrário de outros ambientes tais como as cidades industriais, comunidades e firmas tendem a se fundir.

A característica distintiva do distrito em termos de competitividade é que ela está baseada na forma como a manufatura é organizada para a confecção do produto (SEGENBERGER; PYKE, 1991), o qual apresenta características locais (PIORE, 2001). ${ }^{11}$ Isso é diferente de fundamentar a

11 Piore (2001, p. 346-347) expõe da seguinte maneira essa visão: "[A] vantagem competitiva do distrito industrial está em sua capacidade em produzir produtos novos e únicos. Por esta razão, ele tem uma vantagem competitiva que é particular à localidade e não muda em resposta a mudanças nos preços relativos dos fatores. Ela é então uma forma mais durável e robusta de vantagem local". 
competitividade na posse de alguma vantagem comparativa associada a recursos escassos ou no baixo custo de mão-de-obra.

Dei Ottati (2002) considera que os elos sociais e os fatores institucionais mantêm a vantagem competitiva do produto do distrito. Em seu ponto de vista, o pacto social que se estabelece no distrito pode ser resultado de relações sociais diárias que conformam determinadas regras e procedimentos que estão implícitos no comportamento dos agentes. Esse pacto seria um tipo de mecanismo regulador que mitigaria a ocorrência de comportamentos oportunistas, que em sua presença poderia levar à integração vertical, restringindo o processo de divisão social do trabalho. ${ }^{12}$ As relações estabelecidas no dia-a-dia entre membros do distrito, ao estabelecer um clima de confiança mútua, gera o que a literatura denomina de capital social, um tipo de ativo ou bem público que, através dos elos sociais criados, permite ter acesso a informações e oportunidades, levando a obtenção de ganhos econômicos. A autora atribui ainda um peso importante à mediação realizada pelo governo local, dado que é portador de legitimidade social de intervenção e de busca do desenvolvimento da comunidade. A implicação de política pública dessa visão é que o adensamento do distrito industrial pode ser alcançado mediante ação pública adequada.

As vantagens da organização sob a forma de cluster ou distrito industrial é que ela permite flexibilidade da produção às variações da demanda, redução nos custos de transação devido ao controle social sobre comportamentos oportunistas, e fornece ambiente que possibilita a criação e difusão tecnológica, dado que as informações fluem mais facilmente quando relações face-a-face, baseadas em confiança e em comportamentos solidários, são renovadas diariamente.

Mas nessa forma de arranjo produtivo, como se mencionou, a renovação da competitividade do produto não é garantida somente pela cooperação, cuja coordenação é realizada pelo mercado. É necessária também a presença de instituições que auxiliem no acesso ao conhecimento tecnológico através do fornecimento de serviços reais, apoiem o ingresso de empresas em novos mercados, defendam os interesses coletivos do aglomerado, entre outros.

Uma particularidade de distritos industriais encontra-se em seu desenvolvimento espontâneo, associado à região onde ocorre a atividade, a qual apresenta características que a distinguem pela cultura, história,

12 Nem sempre a integração vertical se deve a uma estratégia para evitar a possibilidade de comportamento oportunista. Há situações em que os requisitos de adequação a normas de produção ou a exigências do consumidor em relação ao produto ou ao serviço a ser adquirido não podem ser controlados pela empresa contratante, necessitando internalizá-los em seu processo produtivo. 
predicados físicos, entre outras, e, portanto, não é de se esperar encontrar esses mesmos atributos em espaços geográficos distintos, particularmente localizados em outros continentes. É essa natureza mais empírica que teórica do conceito de distrito (BIANCHI, 1998) que dá margem na literatura a diferentes denominações a essas configurações, et pour cause também de divergências interpretativas. É por isso que alguns autores (AMIN; ROBINS, 1990; VARALDO; LUCA, 1996; e outros) questionam a possibilidade de replicar tutti quanti esse tipo de arranjo em outros ambientes que são distintos em geografia, economia e relações sociais. Contudo, outros autores (RIPOLL, 1999; e outros) defendem que, mutatis mutandis, pode-se utilizar essa experiência como guia de ações em outras regiões com históricos de formação diferente.

Todavia não se deve perder de vista que na atividade do distrito a concorrência não é eliminada, dado que o ambiente em que as empresas atuam é capitalista. Nesse modo de produzir, empresas que se dedicam às mesmas atividades entram em disputa por fatias de mercado, pois a concorrência é da natureza do sistema. ${ }^{13}$ São as forças coercitivas da concorrência que forçam as empresas a adotarem as práticas produtivas mais eficientes e, também, a busca de inovações que lhes permitam posicionarse favoravelmente na luta competitiva. No ambiente do distrito coexistiria, então, um mix de cooperação e competição.

Avançando além de seu sentido genérico de princípio constitutivo do sistema, a competição pode ocorrer com base em diferentes atributos: preço, design, qualidade, entre outros. Conforme Ferraz, Kupfer e Haguenauer (1995, p. 6), embora exista essa amplitude de fatores de competição, "[...] em cada mercado predomina uma ou um subconjunto dessas formas como fatores críticos de sucesso competitivo". A forma dominante constitui o padrão de competição no mercado que, inclusive, subordina a direção da cooperação. Sengenberger e Pyke (1991) mencionam que as estratégias de adaptação dos distritos aos desafios competitivos internacionais podem seguir trajetórias diferenciadas. A chamada low road caracteriza-se por ter sua performance baseada em algum tipo de competitividade espúria, com baixos salários e flexibilidade numérica no mercado de trabalho. A denominada high road é mais duradoura, pois que alicerçada em inovações e maior eficiência produtiva.

Em diferentes distritos é possível, então, a existência de padrões de competição diferenciados e, com isso, capazes de influir na cooperação

13 Na literatura sobre o assunto, não deixa de perpassar uma certa visão romantizada de que os ganhos individuais ficam subordinados ao desenvolvimento coletivo do distrito, onde os agentes estariam como que irmanados em busca de interesses comuns. Daí a surpresa que estudos manifestam ao constatarem a existência de baixa atividade cooperativa em clusters que são, inclusive, bastante desenvolvidos ou, ainda, de procurarem generalizar para o conjunto do aglomerado, uma que outra relação de cooperação pontualmente encontrada. 
e em outras ações estabelecidas pelos agentes. Quando os fatores em que se alcança competitividade são adquiridos no mercado ou obtidos através de esforços próprios, a atuação das empresas de forma individual é a norma. Mas nos casos em que o desempenho atomizado é insuficiente para lograr competitividade, então é possível o empreendimento de ações conjuntas entre empresas para superar as restrições, em que pese os benefícios poderem ser difundidos entre concorrentes. Notar essas diferenças evitaria interpretações equivocadas ou surpresas sobre a intensidade da cooperação e de comportamentos empresariais encontrados em arranjos produtivos concretos. Ações que requeiram o envolvimento cooperativo têm poucas chances de sucesso se o empreendimento não resultar no fortalecimento da posição competitiva no mercado dos participantes do ato associativo. Por exemplo, a instalação de um centro de design para diferenciar produtos encontraria baixa adesão se o principal atributo de concorrência for preço baixo, a menos que haja a percepção entre os agentes de que pressões competitivas indiquem um ajuste em direção a capacitações em novas bases de competitividade (COSTA; COSTA, 2005). Igualmente, o deslocamento de empresas para territórios diferentes daquele do arranjo produtivo, os quais oferecem condições competitivas mais favoráveis, não é de surpreender, como ocorreu com empresas pertencentes ao cluster de calçados do Vale do Sinos que se instalaram no Nordeste brasileiro a partir da metade da década de 1990, atraídas por custos baixos de mão-de-obra, bem como por incentivos fiscais e financeiros concedidos por governos locais (COSTA; FLIGENSPAN, 1997).

Em suma, e que é importante para o argumento do texto, os determinantes da competitividade do distrito e que fundamentam o atributo do produto sob o qual concorre, condicionam a sua trajetória de crescimento, assim como as relações sociais e as ações de instituições que são desenvolvidas no interior do aglomerado de empresas.

\section{Ação Institucional e Serviços Técnicos}

A solução encontrada para as dificuldades de coordenação e de acesso a conhecimentos, a equipamentos de maior conteúdo tecnológico e a serviços produtivos com que se deparam aglomerados produtivos de pequenas empresas, tem sido a criação de instituições ou de intermediários sociais que transfiram conhecimentos necessários e façam a mediação entre os atores envolvidos na atividade econômica. Dentre essas instituições cabe destacar aquelas prestadoras de serviços técnicos que, atuando como um tipo de infra-estrutura do arranjo produtivo, contribuem para o aumento de sua eficiência e competitividade. 
De acordo com Bellini (2000) esses serviços - chamados de real services [serviços reais] - têm essa denominação derivada da expressão italiana servizi reali, contemplando aquelas atividades enquadradas como de "extensão industrial", de consultoria, serviços de apoio etc. ${ }^{14}$ Segundo aquele autor, os efeitos importantes desses serviços sobre o arranjo produtivo é que eles mudam a relação das empresas com o mercado, tendo igualmente impactos sobre as características estruturais do comportamento empresarial e, por isso, assumindo uma importância estratégica para as ações de política industrial. O papel das instituições que prestam esses tipos de serviços seria o de difundir entre as empresas do aglomerado aquelas best practices que possam ser imitadas e que já estariam sendo empregadas por empresas "virtuosas", de desvendar novas oportunidades de mercado e, de outro, introduzir novos elementos no arranjo a serem explorados pelas empresas. Um exemplo dessa natureza seria a criação de um centro para o desenvolvimento de design, de uso compartilhado por pequenas empresas, sem o que elas não teriam acesso a essa tecnologia.

Há ainda um outro tipo de instituição, ou de intermediário, operando entre as empresas e o Estado, que ajuda no desempenho competitivo daquelas, mas cuja natureza de atuação está baseada no que Bennett (1998) classifica de "lógica da influência", e que se distingue da "lógica dos serviços", mencionados anteriormente. Esse tipo de instituição resulta de agrupamento voluntário entre seus membros (uma associação empresarial, por exemplo) que age coletivamente em benefício dos associados. A representação tem caráter coletivo no sentido de que produz externalidades que alcançam a todos indistintamente como, por exemplo, a representação dos interesses do setor junto a órgãos do governo, o pleito para a redução de impostos sobre o produto ou insumo da atividade econômica a qual pertence, e outros. ${ }^{15}$

Todavia em ambientes de aglomerados produtivos podem ocorrer tanto relações de confiança e de solidariedade entre seus membros, como também comportamentos guiados por autointeresse. A lógica do cálculo mercantil é capaz de prevalecer em casos onde os laços sociais sejam relativamente tênues. Em presença de capital social é possível identificar, ainda, duas proposições acerca do comportamento dos agentes: rational choice e embeddedness. Segundo Anderson e Sarah (2002):

A perspectiva da escolha racional vê o capital social como um recurso básico que os indivíduos usam para os seus próprios fins autointeressados, sem

\footnotetext{
14 De acordo ainda com Bellini, as expressões encontradas na literatura de língua inglesa são: industrial extension services; manufacturing extension services; support services; advisory services; e business services.

15 Em algumas situações a associação empresarial pode desempenhar os dois papéis.
} 
reconhecer qualquer necessidade para além do comportamento egoísta. O conceito de embeddedness [enraizamento] conquanto também denote liberdade individual de ação, ele implica, contudo, alguma forma de reciprocidade ou neutralidade. Em contextos de embeddedness o empreendimento empresarial estaria condicionado ou empurrado em certa direção devido a regras implícitas ou a valores sociais.

Olson ([1971]1999) considera que o envolvimento de empresas e pessoas em associações coletivas é influenciado pelo número total de possíveis participantes no empreendimento. Em grupos pequenos, a probabilidade de que a maioria de seus membros constituintes se junte a uma associação é maior do que aqueles em que a população é relativamente elevada. Quanto maior o número de empresas em um determinado segmento produtivo, mais volátil a adesão como membro voluntário à associação. Em situações em que isso ocorra, algumas empresas, mesmo que não participem de um empreendimento associativo, também acabam se beneficiando dos resultados de ações levadas a cabo pela associação que atua em defesa dos interesses do setor. Além disso, há casos em que potenciais associados - particularmente empresas de pequeno porte não sintam que seus interesses sejam representados na agremiação, seja essa percepção real ou imaginária. Adicionalmente, a falta de maiores informações sobre os serviços que essas instituições oferecem leva a que pequenas empresas não se filiem em associações empresariais.

Contudo, a globalização dos mercados tem transformado as relações nos diferentes âmbitos da sociedade - econômicas, sociais, culturais, e outras -, necessitando de um ajuste dos distintos agentes para se inserir favoravelmente nesse ambiente. No caso de pequenas empresas, para que isso seja possível, seria benéfico contar também com instituições que estejam capacitadas a ajudá-las nessa empreitada.

Pyke (1994) identifica três caminhos que pequenas empresas podem trilhar para posicionarem-se diante de novas pressões competitivas. Pequenas empresas podem procurar contornar suas limitações tecnológicas, gerenciais e de mercados finais, atuando subordinadas a grandes empresas. Contudo, mesmo nessa situação há a necessidade de esforços próprios para se adequar às mudanças no ambiente competitivo de sua contratante. Outra maneira de sobrevivência é estabelecer relações horizontais com empresas semelhantes mediante algum tipo de vínculo - consórcios, associações, e outros. De acordo com Pyke (1994):

Esta inserção em redes regionais potencialmente remove a dependência da grande empresa como o único motor de desenvolvimento e transfere a capacidade de empreender iniciativas pró-ativas a instituições regionais, tais como governos locais, associações empresariais e outras instituições. 
Uma terceira alternativa seria pequenas empresas atuarem individualmente em nichos ou franjas de mercado, em que, por uma questão de escala, não interessam às grandes firmas. Em qualquer dos caminhos mencionados há a necessidade da existência de um marco regulatório e institucional que constantemente ajude as pequenas empresas a se capacitarem para atender a um ambiente dinamizado por inovações e novos concorrentes, que a globalização de mercados engendra.

\section{Instituições, Cooperação e Desempenho Competitivo no Arranjo Calçadista do Vale do Sinos}

A presença agressiva da China e de outros países asiáticos no comércio internacional nos últimos anos com seus produtos baratos têm despertado a apreensão de empresas, trabalhadores e governos de diferentes países. A inquietação gerada deriva não só da competitividade desses concorrentes, mas também da atração que particularmente a China exerce sobre produtores internacionais que para lá deslocam suas atividades ligadas à manufatura em busca de melhores condições para sua performance econômica. Nesse deslocamento, a fabricação de produtos é subcontratada de firmas chinesas ou são feitos investimentos externos diretos naquele local. A consequência é que a luta competitiva torna-se mais acirrada em mercados internacionais e, de um modo geral, com resultado favorável aos produtos oriundos da China. Essa é a situação vivenciada pelos segmentos produtivos do arranjo calçadista do Vale do Sinos, importante aglomerado de empresas na geração de emprego e renda para o País. Para construir um quadro mais nítido acerca dos desafios com que a produção de calçados do Vale se depara, convém rememorar sua trajetória competitiva e de crescimento desde o seu ingresso no mercado externo ao final dos anos 1960.

A produção de calçados no Brasil faz parte daquelas atividades que moldaram a indústria nacional desde o seu início. A sua trajetória de crescimento até o final da década de 1960 esteve associada ao mercado interno. Nesse âmbito os calçados produzidos apresentavam níveis de sofisticação em consonância ao grau de desenvolvimento alcançado pela economia, cuja renda per capita era relativamente baixa quando comparada aos padrões internacionais. A dimensão continental do País e o tamanho da população, por sua vez, permitiram a sobrevivência de uma estrutura industrial de certa magnitude. A inexistência de barreiras à entrada significativas e a difusão da arte de fabricação de calçados constituíram uma organização produtiva formada por pequenas e médias empresas, em aglomerações no espaço geográfico - destacando-se o Vale do Sinos, 
no Rio Grande do Sul, e Franca, no estado de São Paulo - e exibindo, até então, manufatura com marcadas características artesanais. O processo de trabalho era organizado através de "cavaletes" - um tipo de móvel com três ou quatro prateleiras, com rodas em sua base para permitir o seu deslocamento - onde se colocavam os calçados em fase de montagem, e que eram empurrados ao longo do chão-de-fábrica. Os trilhos e a esteira de montagem - com as mudanças no trabalho que os caracterizam - foram implantados a partir do início da década de 1970. O mesmo ocorre com a divisão social do trabalho. Até então as empresas eram integradas produtivamente, fabricando os seus próprios componentes dos calçados. A maior especialização aparece no pós-II Guerra e se amplia com o alargamento do mercado devido às exportações. Em 1974, segundo Humann (2004), ocorre a primeira Feira Internacional de Máquinas e Componentes de Calçados de Novo Hamburgo (FIMEC), constituindo-se em um espaço para a exposição de empresas produtoras de componentes.

A partir de final da década de 1960, o caminho de crescimento do setor sofre uma inflexão diante de seu ingresso no mercado externo. A expansão dessa atividade foi acelerada e extensiva, incorporando recursos e mão-de-obra. Um primeiro lote de exportação é realizado em 1968 e em 1970 exporta-se quatro milhões de pares a um valor de US\$ 8 milhões. Durante os anos 1970 a taxa média de crescimento da produção física foi de $28,5 \%$ ao ano, tendo-se reduzido para $11,3 \%$ anuais na década de 1980, e que se pode considerar ainda bastante elevada. Em 1993, o setor atingiu o seu ápice nessa trajetória em termos de exportações físicas e em valores monetários, quando alcançou 212 milhões de pares e US\$ 1.846 milhões em valores correntes. A partir desse ano as exportações físicas entram em uma fase declinante e que perdura até 2004 quando, então, são exportados 212 milhões de pares e praticamente aos mesmos valores correntes de uma década atrás: US $\$ 1.887$ milhões. Em relação ao número de trabalhadores diretos envolvidos, houve um salto de 71,2 mil trabalhadores em 1970 para 157,3 mil em 1980, 257,6 mil em 1993, e 312,6 em 2004. Essa expansão mudou estruturalmente o setor, havendo uma certa concentração industrial, com os grandes estabelecimentos detendo a maior fração relativa do emprego e das exportações, conforme mostram as Tabelas 1 e 2 a seguir.

Tabela 1 - Distribuição do emprego e dos estabelecimentos das indústrias brasileira e gaúcha de calçados - 2004

\begin{tabular}{c|c|c|c|c|c|c|c|c}
\hline \multirow{2}{*}{ Tamanho (*) } & \multicolumn{4}{|c|}{ Brasil } & \multicolumn{4}{c}{ RS } \\
\cline { 2 - 9 } & $\mathrm{MO}$ & $\%$ & $\mathrm{~N}$ & $\%$ & $\mathrm{MO}$ & $\%$ & $\mathrm{~N}$ & $\%$ \\
\hline Microempresa & 30.350 & 9,7 & 6.386 & 75,7 & 10.147 & 7,1 & 2.247 & 70,4 \\
\hline Pequena & 66.807 & 21,4 & 1.516 & 18,0 & 30.451 & 21,3 & 655 & 20,5 \\
\hline
\end{tabular}


(continuação)

\begin{tabular}{c|c|c|c|c|c|c|c|c}
\hline Média & 89.833 & 28,7 & 436 & 5,2 & 48.867 & 34,2 & 232 & 7,3 \\
\hline Grande & 125.589 & 40,2 & 95 & 1,1 & 53.557 & 37,4 & 58 & 1,8 \\
\hline Total & 312.579 & 100,0 & 8.433 & 100,0 & 143.022 & 100,0 & 3.192 & 100,0 \\
\hline
\end{tabular}

(*) Microempresa: 0 a 19 empregados; Pequena: 20 a 99 empregados;

Média: 100 a 499 empregados; Grande: 500 e mais empregados.

$\mathrm{MO}=$ emprego; $\mathrm{N}=$ estabelecimentos.

Fonte: MTE/RAIS-2004. Elaboração própria.

Tabela 2 - Grau de concentração das exportações brasileiras de calçado - 2004

\begin{tabular}{c|c|c|c|c}
\hline Faixa de embarques & $\mathrm{N}^{\circ}$ de empresas & $\%$ & US\$ milhões & $\%$ \\
\hline Mais de US\$ 50 milhões & 6 & 0,5 & 434,0 & 22,9 \\
\hline US\$ 25 a US\$ 50 milhões & 12 & 0,9 & 411,0 & 21,7 \\
\hline US\$ 10 a US\$ 25 milhões & 28 & 2,2 & 407,0 & 21,4 \\
\hline US\$ 5 a US\$ 10 milhões & 30 & 2,4 & 220,0 & 11,6 \\
\hline US\$ 1 a US\$ 5 milhões & 119 & 9,4 & 304,0 & 16,0 \\
\hline US\$ 0,1 a US\$ 1 milhão & 301 & 23,8 & 106,0 & 5,6 \\
\hline Menos de US\$ 0,1 milhão & 768 & 60,8 & 16,0 & 0,8 \\
\hline Total & 1.264 & 100,00 & 1899,00 & 100,0 \\
\hline
\end{tabular}

Fonte: Abicalçados (2005). Elaboração própria.

Os fatores do sucesso do setor nessa trajetória, contudo, são passíveis de discussão. Schmitz (1999a; 1999b) enfatiza o papel do que chama de "eficiência coletiva", um mix de economias externas de tipo marshalliana e à ação conjunta de atores pertencentes ao aglomerado. As primeiras, de natureza incidental, são geradas a partir da divisão do trabalho entre empresas do distrito e da formação de mercado próprio de mão-de-obra, entre outras, enquanto a segunda decorre de ação consciente de atores no estabelecimento de ações cooperativas entre si, visando a promoção e a defesa do cluster de empresas. O autor reconhece que salários baixos e incentivos fiscais podem ter tido importância, mas os descarta como últimos determinantes do sucesso competitivo do setor. Alega que outras localidades brasileiras também exibiam baixos custos de mão-de-obra e igualmente poderiam ser beneficiárias dos incentivos. Contudo apenas a região do Vale do Sinos e Franca se credenciaram à produção e isso, então, o leva a concluir, seria devido à ação conjunta estabelecidas entre agentes no setor.

Desde logo, é importante salientar que desempenho competitivo, como qualquer desempenho, está sujeito a múltiplas determinações e não é fácil associar um ou poucos elementos específicos como seus determinantes. Contudo a influência da eficiência coletiva como determinante do 
sucesso e do declínio competitivos do setor deve ser considerada apenas como uma hipótese. ${ }^{16}$

Outra interpretação para o desempenho da indústria brasileira de calçados nas exportações pode ser desenvolvida a partir de um mix de custos salariais, de incentivos fiscais e financeiros e do comportamento da taxa de câmbio, mais as propriedades associadas ao cluster de empresas: externalidades positivas e ação de agentes locais na promoção da atividade do setor. Olhando em retrospectiva, firma-se a convicção de que a trajetória competitiva do setor esteve vinculada a custos baixos de produção. A vantagem da abordagem com base em custos é que permite explicar não só o sucesso e as dificuldades da indústria brasileira de calçados no exterior, mas também avançar no entendimento do movimento internacional da produção dessa mercadoria. ${ }^{17}$

A entrada da indústria calçadista brasileira no mercado externo ocorre sob um movimento de transferência da produção desse bem em especial aquele segmento de baixo preço e produção em escala - de países desenvolvidos em direção a regiões que apresentassem melhores condições produtivas, destacando-se nesse aspecto a oferta abundante e barata de mão-de-obra. ${ }^{18}$ A partir do final dos anos de 1960, Estados Unidos, Alemanha, Inglaterra, dentre outros, passam a substituir a manufatura interna de calçados, subcontratando-a em países do então chamado Terceiro Mundo. Ilustração emblemática dessa situação é representada pelos Estados Unidos, maior importador individual de calçados e, desde cedo, o principal comprador dos calçados brasileiros. Em 1960 aquele país importava apenas $4 \%$ de seu consumo total de calçados, enquanto em 1968 atingia $21,4 \%$, e em 2004 essas importações já correspondiam a 98,4\% do total. ${ }^{19} \mathrm{~A}$ Coreia do Sul mostrou trajetória semelhante à brasileira, pois

16 Observe-se que se está considerando a limitação do conceito apenas no que se refere à explicação do desempenho da produção de calçados no Brasil, e não a outras situações.

17 O calçado não é uma commodity, pois é um produto de moda. Isso leva a que empresas com diferentes eficiências produtivas sobrevivam no mercado. Atributos vinculados a design, marca e outros, permitem que ocorra segmentação de mercados e que empresas exerçam essa atividade em países de altos salários. Nessas situações, o volume de produção é relativamente menor. Contudo, o grosso do mercado é constituído por produtos em escala e onde o custo é fator de competitividade.

18 O deslocamento da produção de calçados no espaço geográfico é tradicional nessa atividade. Em entrevista para o trabalho de Froehlich (2006), o vice-presidente da Abicalçados interpreta esse movimento como normal: "Nos anos 80, grandes empresas gaúchas como a Azaleia e outras transferiram a produção para cidades fora do Vale do Sinos (RS), e dez anos mais tarde, para o Nordeste. Agora o destino é a China. Depois disso, não sabemos o que irá restar da empresa nacional de calçados. Já era previsível que esse fenômeno poderia acontecer. Há mais de 30 anos, o Brasil fez exatamente o que a China faz hoje. Com custos baixos e mão-de-obra barata, roubou [sic] a produção de países como Espanha e Portugal, tornando-se um grande centro internacional de produção terceirizada".

19 Para 1960, ver <http://informat.com/research>; acesso em 11/05/2004. Para os anos de 1968 e 2004, ver < http://www.apparelandfootwear.org > . 
sua indústria de calçados ingressa no mercado externo quase em simultâneo com a congênere brasileira. Em 1965 suas exportações de calçados foram de US\$ 4,2 milhões, aumentou para US\$17,9 milhões em $1970 \mathrm{e}$ ampliou para US\$904,2 milhões em 1980. O pico de suas exportações foi alcançado em 1990, quando exportou US $\$ 4,3$ bilhões em calçados. De 1990 em diante o setor experimenta - à semelhança da indústria brasileira de calçados - uma fase de declínio, caindo as exportações de calçados em 1998 para US $\$ 810,4$ milhões. $^{20}$

O sucesso das exportações brasileiras de calçados residiu em um conjunto de elementos que se conjugaram à época, podendo-se destacar os baixos salários e oferta abundante de mão-de-obra, os incentivos fiscais e financeiros e taxa de câmbio favorável, junto de ações de agentes locais na promoção do setor. No que se refere ao mercado de trabalho, esse nunca se constituiu em entrave à produção de calçados no Brasil, apresentando, inclusive, flexibilidade numérica. No Vale do Sinos, além da ampliação da absorção de trabalhadores nos próprios municípios onde estavam sediadas as empresas, houve também a atração de trabalhadores de outras regiões do estado do Rio Grande do Sul através de campanhas realizadas pelas empresas, contando, em alguns casos, com o apoio de governos locais. O nível salarial do grosso dessa mão-de-obra manteve-se entre 2 a 2,5 salários-mínimos, a qual, ainda, apresentava baixo grau de escolaridade (COSTA, 1995). Por volta de 1970 o governo brasileiro adotou um programa de incentivos fiscais às exportações. De acordo com Lagemann (1986), o volume de incentivos relacionados ao imposto sobre circulação de mercadorias (ICM) concedido a empresas de calçados do Vale do Sinos tinha alcançado a cifra de US $\$ 588,6$ milhões no período 1973-1985. Em agosto de 1968 o governo brasileiro inicia a prática da política de minidesvalorizações cambiais com o objetivo de manter competitivas as exportações da economia (COSTA, 2004).

O porquê de o Vale do Sinos e Franca se credenciarem às exportações deve-se a um fato que pode ser considerado trivial. Há muito nessas regiões havia se desenvolvido de maneira estruturada a produção de calçados. No primeiro caso, essa atividade data de 1824, a partir da chegada de imigrantes alemães no Sul do país. Em Franca, um pouco mais tarde, com a colonização feita por imigrantes italianos. Nada mais natural, então, que tenham sido essas as regiões escolhidas para sediar as exportações

20 Dados disponíveis em < http://www.shoedb.com/pds/pass/kfia.htm >; acesso em 07/06/2004. A partir desse comportamento das exportações coreanas se coloca uma questão interessante e que necessita de maiores investigações sobre o papel da eficiência coletiva na explicação do desempenho competitivo da indústria calçadista. Teria a eficiência coletiva também se manifestado nos mesmos períodos na Coreia do Sul? Pois o início tanto do sucesso como do declínio das exportações desse país asiático ocorre quase que em simultâneo - em um intervalo de 25 anos - com aquele do Brasil. 
de calçados do país. Obviamente, a presença em si de mão-de-obra de baixo custo não assegura exportação alguma. Há a necessidade de uma estrutura produtiva mínima que garanta a efetividade da produção. É igualmente óbvio que a simples presença de estrutura produtiva não significa acesso automático a mercados. Vender em mercados geográficos diferentes daquele em que se atua deve fazer parte de estratégias empresariais e essa preocupação é comum nos negócios. Isso ocorreu no setor com missões comerciais e realização de feiras, devendo-se ressaltar essa iniciativa de empresários e de lideranças do setor. Apesar de seu importante papel para as exportações, a missão empresarial que visitou os Estados Unidos para prospectar novos mercados ocorreu em dezembro de 1960 , tendo esses pioneiros ${ }^{21}$ constatado que as empresas brasileiras estavam defasadas tecnologicamente e não tinham escala para atender os pedidos, que alcançavam inicialmente, de acordo com a ABAEX (s.d.), um volume de 120 mil pares de sandálias. A Feira Nacional do Calçados (FENAC), por sua vez, fundada em 1961, dá início às suas atividades com a realização da primeira feira em 1963, mas é apenas ao final daquela década que as exportações tiveram um começo efetivo. Foi necessário ainda um persistente trabalho por parte de alguns empresários em tentar vender no exterior. Depoimento de Bruno Petry, um dos participantes da missão aos Estados Unidos, ilustra essa situação de falta de estrutura para atender às exportações: "Tivemos que investir muito em máquinas e mão-de-obra. Minha empresa só foi iniciar efetivamente a exportação uns dez anos mais tarde".22

A inserção do setor no comércio exterior apresentou uma característica particular. Deu-se apenas com capacidade manufatureira, atuando de forma subcontratada, em segmentos de calçados de baixo preço. Agentes de exportação intermediavam pedidos de importadores junto aos fabricantes locais. O preço, os modelos dos calçados, a marca e a comercialização ao consumidor final eram determinados pelo importador. Esse é um modelo organizacional que, grosso modo, permanece até os dias atuais.

Desde meados dos anos 1990 a indústria calçadista brasileira vem se defrontando com dificuldades competitivas. Desse ano até 1999 o setor de calçados brasileiro entra em uma fase de declínio, devido à forte valorização da taxa de câmbio em decorrência do programa de estabilização da economia (o chamado Plano Real estabelecido em julho de 1994). ${ }^{23}$

21 Um dos primeiros empresários a exportar foi Cláudio Strassburguer.

22 <http://leather.com.br/interna/links_valesapato2.asp>. Acesso em 12/06/2002.

23 De julho de 1994, quando foi implementado o Plano Real, até o final daquele ano, a taxa de câmbio (R \$/US\$) foi inferior a um dólar, alcançando em 30/12/1994 o valor de R $\$ / \mathrm{US} \$ 0,84$. A taxa de câmbio só ultrapassou o valor de R\$1,00 por US\$ em 12/06/1996, ao atingir o valor de 1,0007. Em 31/12/1998 a taxa foi de R \$1,21 por US\$. Em janeiro de 1999, o governo 
As estatísticas no período 1993-1999 mostram que o setor amarga uma queda nas exportações de calçados de US $\$ 568$ milhões, assiste a penetração de calçados chineses em seu mercado doméstico e a demissão de milhares de trabalhadores, particularmente no Vale do Sinos. Diante dessa situação o setor adota uma estratégia de ajuste, mesclando modernização produtiva, demanda por proteção comercial e deslocamento de unidades de produção em direção ao Nordeste brasileiro. O móvel desse deslocamento é basicamente os incentivos fiscais, financeiros e de custo de mão-de-obra, oferecidos por Estados daquela região na atração de empresas, pois não contam com um cluster calçadista como aqueles do Vale do Sinos e de Franca (COSTA; FLIGENSPAN, 1997). Já Schmitz (1999a), para manter coerência com o seu conceito de eficiência coletiva, atribui os problemas enfrentados pelo setor no período à desarticulação e divergências entre entidades ligadas à atividade e ao comportamento individualista de grandes empresas, que deram preferência ao estabelecimento de relações com os importadores em vez de juntar esforços em prol do cluster. ${ }^{24}$

As medidas adotadas pelo governo brasileiro, particularmente a proteção comercial direta ao setor e a desvalorização do câmbio devida a pressões de mercado, de um lado, a reestruturação e o deslocamento de empresas para o Nordeste brasileiro, de outro, proporcionaram um alívio ao setor. Contudo os anos iniciais desse século 21 mostram que o setor continua enfrentando dificuldades competitivas em seus mercados de atuação. No exterior, a participação no seu principal mercado - os Estados Unidos - tem declinado diante da produção oriunda da China. A evolução da presença chinesa naquele mercado é emblemática da importância do custo da mão-de-obra na competitividade de segmentos de calçados em âmbito internacional, bem como na geografia de sua fabricação. Em 1985 a China contribuía pouco no consumo americano de calçados. Em 1990 a sua presença já era de 35,3\% das importações e em 2004 alcançou 83,5\% dos 2,1 bilhões de pares de calçados importados pelos EUA. O Brasil, por sua vez, que contribuía em 1990 com 9,2\%, chegou em 2004 com apenas 4,7\% das importações americanas de calçados (AAFA, 2004). Em

brasileiro altera o regime cambial da economia, permitindo a flutuação do valor da moeda nacional. A taxa de câmbio nominal para transações comerciais saltou de $\mathrm{R} \$ / \mathrm{US} \$ 1,21 \mathrm{em}$ $12 / 01 / 1999$ para $\mathrm{R} \$ / \mathrm{US} \$=1,98 \mathrm{em}$ 29/01/1999, um aumento nominal de 63,6\% em menos de um mês. Em 30/09/2002 a taxa alcançou R\$/US\$ = 3,89 e em 31/10/2006 o valor havia caído para R $\$ 2,14$ por US $\$$ (<www.ipeadata.gov.br >; acesso em 08/12/2006).

24 Não podemos perder de vista que, embora estando em um cluster, as empresas são capitalistas, sujeitas às ações das forças coercitivas da concorrência, e, portanto, competitividade é uma questão crucial para sua permanência no mercado. Em ambientes dessa natureza podem ocorrer comportamentos solidários ma non troppo, pois a lógica mercantil tende a prevalecer diante da ameaça à sobrevivência empresarial. 
seu mercado doméstico o Brasil tem assistido também a uma penetração dos calçados chineses, responsáveis em 2004 por 81,9\% das importações brasileiras de calçados, embora representassem, segundo a Abicalçados (2005), apenas 1,2\% da produção física total do setor estimada em 755 milhões de pares.

Esse quadro de dificuldades não parece ser conjuntural. Para a indústria brasileira de calçados e particularmente para o Vale do Sinos, que representa 70,0\% dos valores exportados, a competição com base em preço torna-se cada vez mais difícil diante das melhores condições oferecidas pela China e outros países asiáticos. A busca de saída para essa situação tem direcionado o setor para diferentes caminhos e, nessa fase, as alternativas ainda estão sendo testadas. A competição centrada em preço, contudo, parece estar alcançando os seus limites. Embora custo ainda seja importante, ações para desenvolver outros fatores são também necessárias, entre elas a busca por diferenciação de produtos e atuação mais direta junto a importadores e a consumidores finais no exterior. Nesse âmbito, a heterogeneidade de empresas do Vale do Sinos, em termos de capacitações, as têm levado para diferentes estratégias de ajuste. Grandes empresas têm continuado em sua estratégia de deslocar unidades fabris para o Nordeste brasileiro. Paralelamente, devido à sua relativa autonomia no acesso a recursos e no desenvolvimento de capacitações produtivas, buscam também atuar com marca própria, diversificar mercados no exterior e, mesmo quando produzem sob a forma subcontratada, têm procurado vender diretamente para o importador final, contornando a intermediação de agentes de exportação. As pequenas empresas, por sua vez, devido às fragilidades de acesso a recursos, associadas ao seu tamanho, necessitam de apoio para desenvolver capacitações que lhes permitam posicionar-se competitivamente diante desse novo quadro. Nesse âmbito as instituições de apoio desempenham papel relevante no auxílio a essas empresas. Contudo, transitar de um padrão de competição em que o custo é o fator de competitividade para um outro que solicite novos conhecimentos e recursos, bem como na exploração de novas oportunidades, requer que empresas e instituições locais estabeleçam novos tipos de relacionamento e maior aproximação. ${ }^{25}$ Atuar nessa direção exige também uma orientação das ações dessas instituições não só

25 Migrar para outros atributos de competitividade, diferenciados e de maior valor agregado, não é uma tarefa trivial, pois a estrutura do setor tem no preço o seu principal alvo de concorrência. O depoimento de um executivo da Paquetá Calçados, uma grande empresa exportadora do setor, fornece uma ideia das causas dessa dificuldade: "É a visão de calçados baratos produzidos no Brasil, ou seja, a dificuldade em introduzir calçados de maior valor agregado, pois o mercado externo ainda percebe o Brasil como produtor de calçados de baixo valor agregado" (FROEHLICH, 2006). 
na prestação de serviços ligados à eficiência produtiva, mas em oferecer serviços que capacitem as empresas a competirem em novos atributos. Do lado das empresas há a necessidade de uma maior aproximação com essas instituições locais e também de esforços individuais para a criação de identidade própria no mercado. Isso, enfim, implica ajustar empresas e instituições ao novo quadro colocado pelo acirramento da concorrência nos mercados internacionais.

A atuação de instituições locais no arranjo calçadista do Vale do Sinos é antiga (Tabela 3). A formação mais densa de seu arranjo institucional ocorre em paralelo ao ingresso do setor no mercado externo. Até 1970 a existência de instituições de representação setorial era relativamente limitada. Das que se encontram em atividade, apenas a Associação Comercial, Industrial e de Serviços de Novo Hamburgo, Campo Bom e Estância Velha - ACI-NH/CB/EV (inicialmente, apenas ACI-NH) e a Feira Nacional do Calçado - FENAC, além das duas maiores instituições de ensino universitário da região - a Unisinos e a Feevale - e dos órgãos vinculados ao Serviço Nacional da Indústria - SENAI, são anteriores à década de 1970. A ação dessas instituições em prol do desenvolvimento do setor é reconhecida e tem desempenhado relevante papel para a atividade calçadista. Com o crescimento das exportações houve uma ampliação da divisão social do trabalho e o estabelecimento de uma institucionalidade oriunda da consolidação de múltiplos interesses setoriais e de segmentos que iam sendo criados à medida que o setor se desenvolvia.

Tabela 3 - Data de fundação de instituições no arranjo calçadista do Vale do Sinos

\begin{tabular}{l|c}
\hline \multicolumn{1}{c|}{ Instituição $\left(^{*}\right)$} & Data de Fundação \\
\hline $\begin{array}{l}\text { ACI-NH/CB/EV (Associação Comercial, Industrial e de Serviços } \\
\text { de Novo Hamburgo, Campo Bom e Estância Velha) }\end{array}$ & 1920 \\
\hline SENAI-CT Calçado (Centro Tecnológico do Calçado SENAI) & 1946 \\
\hline FENAC (Feira Nacional do Calçado) & 1961 \\
\hline SENAI-CT Couros (Centro Tecnológico do Couro SENAI) & 1965 \\
\hline UNISINOS (Universidade do Vale do Rio dos Sinos) & 1969 \\
\hline FEEVALE (Centro Universitário Feevale) & 1970 \\
\hline $\begin{array}{l}\text { ABQTIC (Associação Brasileira dos Químicos e Técnicos da Indústria } \\
\text { do Couro) }\end{array}$ & 1971 \\
\hline $\begin{array}{l}\text { IBTeC (ex-CTCCA) (Instituto Brasileiro de Tecnologia do Couro, Calçados } \\
\text { e Artefatos) }\end{array}$ & 1972 \\
\hline $\begin{array}{l}\text { FIMEC (Feira Internacional de Máquinas e Componentes de Calçados } \\
\text { de Novo Hamburgo) }\end{array}$ & 1974 \\
\hline AICSul (Associação das Indústrias de Curtume do Rio Grande do Sul) & 1976 \\
\hline
\end{tabular}


(continuação)

\begin{tabular}{l|c}
\hline ABICALÇADOS (Associação Brasileira das Indústrias de Calçados) & 1983 \\
\hline $\begin{array}{l}\text { ASSINTECAL (Associação Brasileira de Empresas de Componentes } \\
\text { para Couro, Calçados e Artefatos) }\end{array}$ & 1983 \\
\hline ABAEX (Associação Brasileira dos Agentes de Exportação de Calaçados) & 1987 \\
\hline ABECA (Associação Brasileira de Estilistas de Calçados e Afins) & 1989 \\
\hline $\begin{array}{l}\text { ABRAMEQ (Associação Brasileira das Indústrias de Máquinas } \\
\text { e Equipamentos para os Setores do Couro, Calçados e Afins) }\end{array}$ & 1992 \\
\hline
\end{tabular}

(*) Há ainda a atuação de entidades como o SEBRAE-RS (Serviço de Apoio às Micro e Pequenas Empresas), de atuação em âmbitos estadual e nacional, prefeituras, governos estadual e federal, sindicatos empresariais e de trabalhadores, bem como jornais, revistas e boletins, que difundem informações sobre os segmentos do arranjo.

Fonte: Elaboração própria.

A criação de entidades de representação setorial particulares como a dos curtumes (AICSul), dos produtores de componentes (ASSINTECAL), dos próprios calçadistas (ABICALÇADOS) e de fabricantes de máquinas para calçados (ABRAMEQ) ocorre após 1970. De um modo geral, a maioria dessas entidades surge oriundas da ACI-NH. No caso da ABAEX, segundo Klein (1991), ela surge a partir de iniciativa de agentes de exportação na criação de uma entidade própria. No âmbito de atendimento através de fornecimento de serviços reais, o IBTeC, criado em 1972 como Centro Tecnológico do Couro, Calçados e Afins, veio se juntar ao SENAI (Serviço Nacional da Indústria), instituição vinculada à Federação das Indústrias em nível nacional. Em que pese a importância das instituições para o setor, o envolvimento de empresas individuais em associações varia entre os segmentos do arranjo produtivo e pode-se considerá-lo, de um modo geral, relativamente baixo. ${ }^{26} \mathrm{~A}$ Tabela 4 abaixo informa algumas dessas instituições e o número de empresas a elas associadas.

Tabela 4 - Grau de participação associativa de empresas em instituições do arranjo calçadista do Vale do Sinos

\begin{tabular}{c|c|c|c|c}
\hline \multirow{2}{*}{ Instituição } & \multicolumn{2}{|c|}{$\begin{array}{c}\mathrm{N}^{\circ} \text { de empresas no setor de atuação da } \\
\text { instituição }\end{array}$} & $\begin{array}{c}\text { Associados em } \\
\text { âmbito nacional }\end{array}$ & \multirow{2}{*}{$\begin{array}{c}\% \\
\text { BR }\end{array}$} \\
\cline { 2 - 5 } & $\mathrm{RS}$ & $\mathrm{BR}$ & 53 & 41,1 \\
\hline ABRAMEQ (2006) & 109 & 729 & 64 & 8,6 \\
\hline AICSul (2004) & 208 & 8.433 & 111 & 1,3 \\
\hline ABICALÇADOS (204) & 3.192 & \multicolumn{3}{c}{ (continua) } \\
\hline
\end{tabular}

26 A ASSINTECAL, até 1996, contava com apenas 17 associados. Em 2002 esse número saltou para 127 e alcançou 302 em 2006, de acordo com informações de 31/03/06 do Relatório de Gestão 2002-2004/2004-2006 dessa instituição. 


\begin{tabular}{c|c|c|c|c}
\hline ASSINTECAL (2006) & 783 & 1.515 & 302 & 19,9 \\
\hline IBTeC (2005)* & 4.292 & 10.824 & 286 & 2,8 \\
\hline
\end{tabular}

(*) Foi considerada a soma dos associados das quatro instituições acima.

Fonte: Elaboração própria com base em informações diretas e em sites das instituições.

Embora essas instituições tenham abrangência nacional, as suas sedes estão localizadas no Vale do Sinos, no estado do Rio Grande do Sul. Para ser membro dessas entidades, a empresa associada paga uma taxa anual, que varia com o porte da empresa: micro, pequena, média e grande empresa. Contudo, não precisa necessariamente ser associada para a empresa ter acesso aos serviços tecnológicos oferecidos. Nesse caso, o custo do serviço é mais elevado do que para associadas. São variados os serviços que essas instituições prestam aos segmentos produtivos que compõem o arranjo calçadista do Vale do Sinos. O Instituto Brasileiro de Tecnologia do Couro, Calçado e Artefatos - IBTeC e o Centro Tecnológico do Calçado SENAI são duas instituições que se destacam na capacitação tecnológica de empresas do arranjo. O Centro Tecnológico do Calçado - SENAI atua principalmente na formação de mão-de-obra para o setor, na assessoria tecnológica, no controle da qualidade por meio de laboratório e na área do meio-ambiente. Os serviços prestados vão desde cursos nas diferentes fases da produção do calçado e no planejamento da produção, implantação de normas de qualidade e de gestão ambiental, ensaios físicos-mecânicos, análises químicas e outros. O Centro conta com escola regular na educação técnica de jovens e dispõe de "fábrica" com instalações para a prática na fabricação de calçados com duas linhas de produtos: feminina e masculina.

O IBTeC, fundado em 1972, por iniciativa de empresários do setor, oferece serviços tecnológicos às empresas dos diferentes segmentos do arranjo. O Instituto realiza testes físico-mecânicos e emite laudos de certificação. Nesse âmbito, segundo entrevista realizada pelo autor, é comum que empresas de calçados recebam encomendas, inclusive de importadores, em que se requer a certificação do produto, no sentido de garantir que o lote produzido esteja conforme às especificações solicitadas e às normas técnicas vigentes. Esse serviço é prestado a um custo associado ao tamanho da empresa, permitindo acesso a mercados que, na sua ausência, seria inviabilizado. ${ }^{27}$ Já as grandes empresas, essas possuem equipamentos para testes biomecânicos para realização de até 5 a 10 tipos de testes que são necessários para acompanhar a qualidade do produto na linha de produção. Seria muito dispendioso - pelo volume de calçado que produzem

27 Uma possível explicação para o baixo associativismo de empresas e de uso dos serviços dessas instituições é não só relativo ao seu custo para as empresas, mas também pelo fato de o modelo de calçado ser definido pelo importador que, inclusive, chama para si a responsabilidade pelo controle da qualidade da produção encomendada. 
- que essas empresas tivessem que parar a linha até o calçado ser testado junto a instituições credenciadas.

Outras instituições como, por exemplo, a ASSINTECAL e a ABICALÇADOS atuam na abertura de oportunidades de mercado, apoiando e coordenando empresas do setor na participação em feiras internacionais, na atração de compradores, no aluguel de estandes, na organização de material de divulgação de produtos, dentre outros. Um exemplo é o Programa Brazilian Footwear de promoção de exportações desenvolvido pela ABICALÇADOS em parceria com a Agência de Promoção de Exportações e Investimento - APEX. Essas instituições - incluem-se ainda em seus respectivos setores a AICSul e a ABRAMEQ - atuam também na representação junto a organismos governamentais e outros que beneficiam o coletivo de empresas vinculadas ao seu segmento.

A Tabela 5, abaixo, informa o tipo de serviços reais mais frequentemente utilizados por empresas do arranjo calçadista gaúcho, a partir de pesquisa direta feita pelo autor com 16 empresas do setor em 2006.

Tabela 5 - Serviços reais utilizados por empresas do arranjo calçadista do Vale do Sinos - 2006

\begin{tabular}{l|c}
\hline \multicolumn{1}{c|}{ Tipo de serviço } & Frequência $\left(^{*}\right)$ \\
\hline Treinamento de mão-de-obra & 8 \\
\hline Testes de materiais e análises químicas & 8 \\
\hline Participação em feiras & 6 \\
\hline Informações de mercado e outras & 2 \\
\hline Assessoria administrativa & 1 \\
\hline Assessoria de produção & 1 \\
\hline Auxílio jurídico & 1 \\
\hline Outros (especificar): Projeto Conforto - SENAI & 8 \\
\hline Não utilizam serviços & \\
\hline \multicolumn{2}{c}{ Base de respondentes: 16 empresas } \\
\hline
\end{tabular}

(*) Cabia assinalar mais de uma alternativa de resposta.

Fonte: Pesquisa de campo do autor.

Embora muitas empresas não utilizem os serviços oferecidos por instituições ligadas à atuação tecnológica e de capacitação de recursos humanos, algumas delas o fazem. Como se vê na Tabela 5, a maior parte das consultas recai em aspectos vinculados à fabricação. Contudo, a existência dessas instituições de apoio não tem sido suficiente para fazer com que o cluster de empresas de calçados supere suas dificuldades competitivas, oriundas da presença nos mercados interno e externo de competidores de custos baixos de produção. Obviamente, a situa- 
ção do setor poderia ser pior sem a presença dessas instituições. Isso mostra, por outro lado, que os caminhos para superar as ameaças não são fáceis de distinguir. Uma iniciativa que vem se difundindo no setor é procurar se diferenciar no mercado mediante o desenvolvimento de design, de marca própria e, em casos de produção subcontratada, vender diretamente ao importador. Empresas de grande porte como a Azaleia, a Paquetá e outras, já têm presença no mercado externo com produção de marca própria. Pequenas e médias empresas encontram maiores dificuldades em trilhar esse caminho, em função de suas limitações financeiras e de organização. Contundo esse não é um obstáculo intransponível para esses portes de empresas. Schuh (2006), em pesquisa com pequenas empresas de calçados do Vale do Sinos, encontrou que algumas delas já colocam alguma produção com sua marca em países da América Latina.

A preocupação de instituições do arranjo calçadista do Vale do Sinos com o design enquanto instrumento que produza diferencial competitivo, de maneira mais organizada, é relativamente recente. ${ }^{28}$ Em 1999, a Assintecal aprovou um projeto relacionado ao design de matrizarias junto a Agência de Promoção de Exportações e Investimentos - APEX e a partir de 2002 criou o Núcleo de Design Assintecal, cujo objetivo é efetuar pesquisa de temas e tendências. Feita a pesquisa, a equipe se reúne com os fabricantes de materiais e passam a eles essas tendências para o desenvolvimento de materiais. Trabalham com consultores e designers através do Fórum de Design, Tecnologia de Materiais para Couro, Calçado e Artefatos. O IBTeC também está iniciando uma atuação na área de Design e Moda. Conta com dois designers. Por exemplo, a criação de modelos de calçados é repassada a empresas interessadas, ou empresas que tenham alguma ideia de lançamento de um modelo próprio discutem com os técnicos do IBTeC, ou mesmo encomendam um modelo especial. A ideia da atuação é observar todos os itens (técnicos e de conforto) necessários na criação de um modelo próprio desde o início de sua concepção.

A Feevale e a Secretaria de Desenvolvimento e Assuntos Internacionais - SEDAI do governo do estado do Rio Grande do Sul realizaram, no período 2001-2003, convênio para o estabelecimento de um Centro Integrado de Inovação e Design, com sede naquela instituição de ensino, com o objetivo de gerar ações para o aumento do valor agregado do calçado. O Centro realizou várias iniciativas, como o desenvolvimento de coleções para micro e pequenas empresas, eventos de sensibilização e capacitação em design, e disseminação de informações sobre moda e

28 Informações sobre as ações de instituições do setor sobre o design foram obtidas pelo autor através de entrevistas realizadas em 2006. 
tendências. A partir dessa experiência, foi criado na Feevale um curso superior em design para a formação de pessoal capacitado na atuação nos setores de calçados, acessórios, vestuário, jóias, materiais e ergonomia (SCHUH, 2006).

O Centro Tecnológico do Calçado - SENAI presta assessoria em moda e estilismo de calçados e no desenvolvimento de modelos e coleções, buscando capacitar empresas que se cadastram junto a essa instituição. A instituição divulga junto às empresas um caderno de pesquisa sobre as tendências da moda internacional no setor. A apresentação do estudo é realizada em workshops e em feiras. Contudo, a busca de candidatos por treinamento em design, de acordo com essa instituição, é ainda tímida e, obviamente, pode estar associada às dificuldades competitivas que o setor vem atravessando nos últimos anos.

\section{Considerações Finais}

O aumento de pressões competitivas no comércio internacional em decorrência de maior liberalização comercial, do ingresso de novos concorrentes nos mercados, de facilidades de transações comerciais entre países proporcionadas pelas tecnologias de informação e comunicação, entre outras, veio lançar novos desafios competitivos a setores da atividade econômica em diferentes países. Esse é o caso da produção de calçados no Brasil e particularmente do arranjo calçadista do Vale do Sinos, no Rio Grande do Sul, responsável pela maior fatia da produção brasileira de calçados destinada a mercados no exterior.

O modelo de inserção externa dos calçados brasileiros foi bem-sucedido até meados dos anos 1990. A partir daí o setor passa a se defrontar com dificuldades competitivas oriundas de duas fontes. Uma delas é externa e se deve à presença em seus mercados de atuação de novos concorrentes com condições produtivas mais favoráveis, destacando-se a China em particular. A outra fonte de dificuldades que vem se somar a anterior tem origem interna e decorre da política macroeconômica implementada pelo governo brasileiro a partir de julho de 1994, em que se tem colocado com uma de suas prioridades a estabilização econômica. Isso tem sido alcançado, dentre outras medidas, com juros elevados e câmbio apreciado. $\mathrm{O}$ resultado é uma perda de competitividade dos calçados brasileiros nos mercados interno e externo, particularmente nesse último.

A competitividade do setor baseada em preço e que orientou a sua trajetória de crescimento ao longo do tempo parece estar alcançando seus limites. A situação com que o setor se depara em termos competitivos veio para ficar e, então, é necessário buscar novos caminhos de sobrevivência e de crescimento. Obviamente essa não é uma tarefa fácil. O desenvolvimento de novas capacitações que permitam às empresas do arranjo 
competir em novos atributos irá requerer esforços não só das próprias empresas, mas igualmente de instituições locais e de governos em suas diferentes esferas. ${ }^{29}$

A ideia do presente trabalho foi procurar, de maneira exploratória, identificar estratégias que vêm sendo desenvolvidas nessa direção. O que se observa é que, em decorrência de heterogeneidade empresarial do setor, têm sido tentados diferentes caminhos. Grandes empresas ainda buscam manter diferencial competitivo em preço, deslocando unidades de produção para o Nordeste brasileiro. Mas também já procuram estabelecer identidade própria nos mercados através de desenvolvimento de marcas e de vendas diretas ao importador final, mesmo quando de forma subcontratada. As pequenas empresas já percebem a importância de incorporar o design como uma ferramenta de seu dia-a-dia. Contudo, para isso, precisam contar com o apoio de instituições locais e de políticas públicas. Trabalhar nessa direção exige um esforço de adaptação, com o desenvolvimento de uma nova cultura produtiva, onde se valorize a criação. Esse esforço também é exigido de instituições locais. Sob esse aspecto, já se observam ações de instituições vinculadas ao arranjo calçadista do Vale do Sinos em incorporar o design em suas atividades de apoio. Mas, além de se capacitarem na prestação de serviços é necessário que essas instituições e as empresas do arranjo estabeleçam uma maior interação, particularmente envolvendo aquelas unidades produtivas de pequeno porte.

\section{Referências}

AAFA. ShoeStats 2005. Arlington, VA: American Apparel $\mathcal{E}$ Footwear Association, November 2004.

ABICALÇADOS. Resenha Estatística. Novo Hamburgo: Associação Brasileira das Indústrias de Calçados, 2005.

ALCHIAN, A. A.; DEMSETZ, H. Production, Information Costs, and Economic Organization, American Economic Review, 62: 777-795. In: Buckley, P. J.; Michie, J. (ed.) Firms, Organizations and Contracts: a reader in industrial organization. Oxford/New York: Oxford University Press, [1972]1996.

AMIN, A.; ROBINS, K. The re-emergence of regional economies: the mythical geography of flexible accumulation. Environment and Planning D: Society and Space, v. 8, p. 7-34, 1990.

ANDERSON, A. R.; SARAH L. J. The articulation of social capital in entrepreneurial networks: a glue or a lubricant?. Entrepreneurship 8 Regional Development, (14), p. 193$210,2002$.

29 Nessa situação em que empresas devem procurar maior atuação nos mercados - particularmente às de menor porte - aí sim a ação conjunta de empresas e instituições é necessária para que os pequenos empreendimentos ganhem capacitação competitiva em atributos de diferenciação. As grandes empresas, pela sua robustez financeira e de recursos, estão mais bem preparadas para se ajustar a esse quadro. 
BECATTINI, G. The Marshallian industrial district as a socio-economic notion. In: Pyke, F.; Becattini, G.; Sengenberger, W. (eds.) Industrial Districts and Inter-Firm Co-Operation in Italy. International Institute for Labour Studies. Geneva, 2nd impression, [1990] 1992.

. Os Distritos Industriais na Itália. In: Urani, André et al. (orgs.) Empresários e empregos nos novos territórios produtivos: o caso da Terceira Itália. Rio de Janeiro: DPEAA, 1999.

BELLINI, N. Real Services: a re-appraisal. European Planning Studies, v. 8, n. 6, December 2000.

BENNET, R. J. Business associations and their potential contribution to the competitiveness of SMEs. Entrepreneur \& Regional Development, 1998. 10: 243-260.

BIANCHI, Giuliano (1998). 'Requiem for the Third Italy: Rise and fall of a too successful concept'. Entrepreneurship \& Regional Development, 10: 93-116.

CHANDLER, A. D., Jr. Os primórdios da "grande empresa”. In: McCraw, T. K. (Org.). Alfred Chandler: ensaios para uma teoria histórica da grande empresa. Rio de Janeiro: Editora Fundação Getúlio Vargas, 1998.

COSTA, A. B. Reestruturação produtiva e padrão de organização industrial. In: Becker, D. F. (Org.). Competitividade: o (des)caminho da globalização. Lajeado-RS: Editora FATES, 1998.

. A trajetória competitiva da indústria de calçados do Vale do Sinos. In: Costa, A. B.; Passos, M. C. (Orgs.). A indústria calçadista no Rio Grande do Sul. São Leopoldo-RS: Editora Unisinos, 2004.

COSTA, A. B.; COSTA, B. M. Cooperação e Capital Social em Arranjos Produtivos Locais. In: XXXIII Encontro Nacional de Economia (ANPEC), Natal-RN, dezembro 2005.

COSTA, A. B.; FLIGENSPAN, F. B. Avaliação do movimento de relocalização industrial de empresas de calçados do Vale do Sinos. Porto Alegre: SEBRAE-RS/NETIT-UFRGS, mimeo, 1997. 132f.

COSTA, B. M. Os impactos do progresso técnico sobre o emprego, a qualificação e as relações de trabalho: um estudo de caso na indústria de calçados do Rio Grande do Sul. Porto Alegre: IFCH/UFRGS. Dissertação de mestrado. Programa de Pós-Graduação em Sociologia, 1995.

DEI OTTATI, G. Social concertation and local development: the case of industrial districts. European Planning Studies, v. 10, n. 4, p. 449-466, 2002.

FERRAZ, J. C.; KUPFER, D.; HAGUENAUER, L. Made in Brazil: desafios competitivos para $a$ indústria. Rio de Janeiro: Campus, 1995.

FROEHLICH, C. A dinâmica das competências organizacionais: a trajetória do grupo Paquetá. Dissertação de mestrado. Programa de Pós-Gradução em Administração. São LeopoldoRS: Unisinos, 2006.

GURISATTI, P. O Nordeste Italiano: nascimento de um novo modelo de organização industrial. In: Urani, André et al. (Orgs.) Empresários e empregos nos novos territórios produtivos: o caso da Terceira Itália. Rio de Janeiro: DPE3A, 1999.

HUMANN, P. V. Componentes - o setor que abastece as fábricas de calçados. In: Costa, A. B.; Passos, M. C. (Orgs.) A indústria calçadista no Rio Grande do Sul. São LeopoldoRS: Editora Unisinos, 2004.

KLEIN, E. E. La cadena de distribucion y la competitividad de las exportaciones latinoamericanas: las exportaciones de calzado del Brasil. Comision Economica para America Latina y el Caribe - CEPAL, LC/G. 1669, 28 de junio, 1991. 
LAGEMANN, E. O setor coureiro-calçadista na história do Rio Grande do Sul. Ensaios FEE, Porto Alegre-RS, 1986. 7(2): 69-82.

MARSHALL, A. Princípios de Economia. São Paulo: Abril Cultural, [1890]1982.

MARX, K. O Capital: crítica da economia política, v. 1, São Paulo: Abril Cultural, [1867]1983.

OLSON, M. A Lógica da Ação Coletiva: os beneficios públicos e uma teoria dos grupos sociais. São Paulo: Editora da Universidade de São Paulo, [1971]1999.

PIORE, M. J. The emergent role of social intermediaries in the new economy. Annals of Public and Cooperative Economics, 72:3, p. 339-350, 2001.

PIORE, M. J.; SABEL, C. F. The second industrial divide: possibilities for prosperity. New York: Basic Books, 1984.

PYKE, F. Small firms, technical services and inter-firm cooperation. Geneva. International Institute for Labour Studies. Research Series, n. 99, 1994.

RIPOLL, C. L. C. Distritos industriales: experiencias de acción conjunta y cooperación interempresarial para el desarrollo de la pequeña y mediana industria. Revista Espacios, v. 20(2), 1999. Disponível em <www.revistaespacios.com>. Acesso em: 14/09/2004.

SCHMITZ, H. Global Competition and Local Cooperation: Success and Failure in the Sinos Valley, Brazil. World Development, v. 27, n. 9, p. 1627-1650, 1999a.

. Collective efficiency and increasing returns. Cambridge Journal of Economics, 23(4): 465-483, $1999 \mathrm{~b}$.

SCHUH, G. C. O design como diferencial competitivo: um estudo em pequenas empresas calçadistas do Vale do Sinos. Dissertação (Mestrado em Administração), Programa de Pós-Graduação em Administração, São Leopoldo: Universidade do Vale do Rio dos Sinos, 2006.

SENGENBERGER, W.; PYKE, F. Small firm industrial districts and local economic regeneration: research and policy issues. Labour and Society, 16/1, p. 1-24, 1991.

Distritos industriais e recuperação econômica local: questões de pesquisa e de política. In: Urani, André et al. (Orgs.) Empresários e empregos nos novos territórios produtivos: o caso da Terceira Itália. Rio de Janeiro: DPEAA, 1999.

SMITH, A. Investigación sobre la naturaleza y causas de la riqueza de las naciones. México: Fondo de Cultura Económica, [1776]1979.

STABER, U. Inter-firm co-operation and competition in industrial districts. Organization Studies, 19(4), p. 701-724, 1998.

VARALDO, R.; LUCA, F. The evolutionary nature of the firm within industrial districts. European Planning Studies, v. 4, n. 1, February 1996.

YOU, J. Competition and co-operation: toward understanding industrial districts. Review of Political Economy, 6.3, p. 259-278, 1994.

Recebido em: 24/11/2008.

Aceito em: 01/12/2008. 